\title{
Purchase Decision: Was It Affected By Product Innovation? (Purchases In Sour Sally Gandaria City South Jakarta)
}

\author{
Ismeth Emier Osman*, Amalia Mustika, Anita Budiono \\ Sekolah Tinggi Pariwisata \\ *ismeth@stptrisakti.ac.id
}

\begin{abstract}
Product innovation is the functional progress of a product that can make the product better than competitors' products. At least the newest product is better than the previous product. Because if a product has advantages, it will be seen as added value for consumers. This research aims to find out product innovations that influence consumer decisionmaking in buying Youghurt at Sour Sally. This research uses the descriptive correlational method. This study's population are all consumers who have shopped Black Sakura and White Skim at Sour Sally Gandaria City Jakarta. The sampling technique used is non-probability sampling, and the total number of respondents in this study was 89 people. To see the relationship level, the correlation coefficient of 0.662 means that the correlation of product innovation on purchasing decisions at Sour Sally Gandaria City Jakarta is strong and positive. So the purchasing decisions at Sour Sally Gandaria City Jakarta are influenced by product innovation by $43.82 \%$ and $56.18 \%$ influenced by other variables not examined in this study.
\end{abstract}

Keywords: Product Innovation, Purchasing Decisions 
Purchase Decision: Was It Affected By Product Innovation?

(Purchase In Sour Sally Gandaria City South Jakarta)

\section{A. Introduction}

Business development makes many new business competitors inevitable. New business competitors that have sprung up sometimes have their own appeal to consumers, especially in terms of their products. However, with similar products offered, consumers will certainly prefer products that have advantages over similar products. With the creation of business competition in which every business actor competes to create competitive advantages that can attract consumer attention so that the decision to buy products by consumers.

Product development is a strategy for company growth by offering new or modified products for current market segments. Development of product concepts into physical products to ensure that product ideas can be turned into products that can be realized (Kotler and Keller, 2012).

Innovation is needed in a business. Innovation is generally considered an important aspect of some business processes because it can provide a competitive advantage (Anatan and Ellitan, 2009).

Product innovation is the result of developing a new product by a company or industry, both existing and non-existing. For old products that are starting to shrink this is because the market is saturated or all consumers who have bought the product switch to other types of products. Then innovation is needed to replace old products with new, better products. This replacement can be in the form of a totally new replacement product or with the development of old products that are more modern and up to date, so that it can continue to improve consumer desires the decision to purchase the product (Indriany, 2013).

Sour Sally is a local brand of food and drink provider that first appeared in Indonesia, especially in Jakarta in 2008 by specializing itself as a pioneer provider of healthy and using mostly frozen yogurt as the base ingredient. Within 1 (one) year since Sour Sally's presence in the food and beverage business, she has successfully opened 11 outlets in Jakarta. The initial presence of Sour Sally, which successfully attracted consumers' attention, turned out to be a concern for other businesses to create and commercialize similar products.

With the higher product innovation, it is believed that it can get the attention of consumers so that purchasing decisions occur on the products offered. Besides making product innovations that have not yet been found on the market, Sour Sally also offers health benefits from consuming these product innovations. However, the product innovation offered is not necessarily acceptable for consumers to make purchasing decisions, especially if the company's strategy to innovate products is not good or right. It will reduce consumers to decide to buy the product for Sour Sally.

Sour Sally was first established in Indonesia in 2008 by a young businessman named Donny Pramono, who graduated with a Masters Degree from Penn State University, United States. He opened a frozen yogurt-based food business because of his passion for consuming yogurt while in the United States.

Tourism Research Journal, Volume 4 (2), 2020 
Purchase Decision: Was It Affected By Product Innovation?

(Purchase In Sour Sally Gandaria City South Jakarta)

He then brought the formula to Indonesia at the end of 2007. The name Sour Sally itself was taken from the word sour. The choice of the word sour because it regrets the sour yogurt taste. Then the word "Sally" which describes the name of a sweet woman, adjusted to the intended market segment, namely most women. On May 15, 2008 the first Sour Sally outlet was opened in Senayan City, Jakarta. The presence of Sour Sally turned out to have made Sour Sally a pioneer in the business of local brands providing food with the basis of frozen yogurt. In addition to opening outlets in Indonesia such as Jakarta, Bandung, Medan, Surabaya, Bali and Semarang, Sour Sally also opened outlets in Singapore in 2010 .

\section{B. Literature Review \\ Product Definition}

According to Kotler and Keller (2012), products are everything that can be offered to the market to meet wants or needs, including physical goods, services, experiences, events, people, places, property, organizations, information, and ideas.

According to Basu and Sukotjo (2007), product is a complex trait that can be touched or cannot be touched, including packaging, color, price, company and retailer prestige, company and retailer services, which are accepted by buyers to meet and satisfy their needs.

\section{Product Innovation}

Every company is required to innovate its products. Consumers tend to prefer companies that produce products with attractive and innovative features.

Product innovation introduces new products or systems that bring economic success to the company and social success for consumers and the wider community or environment. Share 5 characteristics that affect the level of acceptance of an innovation (Kotler and Keller, 2009):

1. Relative Advantage

The extent to which innovation products look superior to existing products.

2. Compatibility

The extent to which the product of innovation is compatible with the value and experience of individuals in society.

3. Complexity

The extent to which the innovation product is difficult to understand.

4. Divisibility

The extent to which these innovations can be tried in a limited way.

5. Communicability

The extent to which the benefits of using the innovation product can be seen or explained to others. 
Purchase Decision: Was It Affected By Product Innovation?

(Purchase In Sour Sally Gandaria City South Jakarta)

From the above theory, it is concluded that product innovation is one of the important factors in a company's success through innovative products created to satisfy customers.

\section{Purchase Decision}

Consumer behavior becomes the things that underlie consumers to make purchasing decisions. Every purchase decision is very important to make choices that are useful and not useful in meeting their needs and desires.

Purchasing decisions are a series of processes that begin with consumers knowing the problem, finding information about a particular product or brand and evaluating the product or brand how well each of these alternatives can solve the problem, which then a series of these processes lead to purchasing decisions (Tjiptono, 2014). The consumer's decision to buy goods is due to the product's quality and the active marketing carried out by the company (Fitriana et al., 2020). At affordable prices, quality products and services are also in demand by consumers to buy these products (Swantari et al., 2019).

Sangadji and Sopiah, (2013), defines a decision as the choice of an action from two or more alternative choices. A consumer who wants to choose must have alternative choices. Kotler (2002) suggests the purchase process goes through five stages. The stages of consumer purchases include:

1. Problem recognition

The buying process begins with a problem or need that is felt by consumers. Consumers perceive the difference between the desired state with the current situation in order to arouse and activate the decision process.

2. Information search

After consumers feel the need for an item or service, then consumers look for information both stored in memory (internal) and information obtained from the environment (external)

Halal labeling on foreign food products guarantees halal status so that the presence of a halal label on a product is very important for consumption. Halal food products are based on a belief in halal food that is closely related to religious commitments (Mustika and Ahmadi, 2018).

1. Validation of alternative

After the information is obtained, consumers evaluate various alternative choices in meeting those needs.

2. Purchase Decision

Consumers who have made choices about various alternatives usually buy the most preferred product, which forms a decision to buy.

3. Post purchase behavior

Consumer satisfaction or dissatisfaction with a product will affect subsequent buying behavior. If satisfied, consumers will most likely make a repeat purchase and vice versa. Consumer dissatisfaction will occur if consumers experience unfulfilled expectations.

Tourism Research Journal, Volume 4 (2), 2020 
Purchase Decision: Was It Affected By Product Innovation?

(Purchase In Sour Sally Gandaria City South Jakarta)

\section{Framework}

Factors that influence Product Innovation and Product Purchasing Decisions at Sour Sally are shown in the chart below:

\begin{tabular}{|c|c|}
\hline $\begin{array}{c}\text { Purchase } \\
\text { Inovation } \\
\text { Decision }\end{array}$ \\
\hline
\end{tabular}

\section{Research Methodology}

This research is a descriptive correlational research method (Descriptive Correlational Method). This study's population is all consumers who have purchased Black Sakura and White Skim at Sour Sally Gandaria City Jakarta. Product innovation can only be seen in frozen yogurt products, namely Black Sakura and White Skim at Sour Sally Gandaria City, Jakarta.

Product innovation can only be seen in frozen yogurt products, namely Black Sakura and White Skim at Sour Sally Gandaria City, Jakarta.

\section{Sample}

The sample is a portion of the population's number and characteristics (Sugiyono, 2001).

The sample technique used is non-probability sampling is a sampling technique by not providing equal opportunities for each element or member of the population to be sampled repeatedly. The sampling technique in this research with certain considerations, namely respondents who meet the criteria set by the researcher (Sekaran, 2004)

It is known that the number of population in Sour Sally Gandaria City Jakarta in one month is 3300 consumers. Primary data collection in this research for approximately one week as many as 770 consumers. Determination of consumers using the Slovin formula

$$
\mathrm{n}=\frac{\mathrm{N}}{1+\mathrm{N}(\mathrm{e})^{2}}
$$

$\mathrm{n}=\mathrm{N} /\left(1+\left(\mathrm{Nx} \mathrm{e}^{2}\right)\right)$

$\mathrm{n}=770 /\left(1+\left(770 \times 0.1^{2}\right)\right)$

$\mathrm{n}=89$

So, the total number of respondents in this study was 89 people

\section{Data Collection Technique}

Data collection techniques used in this research are observation, interview and questionnaire. Observation is namely data collection techniques by directly observing consumers who are the object of research. The interview is collecting

Tourism Research Journal, Volume 4 (2), 2020 
data by means of question and answer with traders and consumers to get accurate data. Questionnaire is namely by circulating a list of questions related to product innovation in consumer decisions to buy products. Data was collected through a questionnaire technique in the form of answers given by respondents.

\section{Descriptive Statistics}

Primary data is processed to obtain the average of each sub-variable and variable to facilitate understanding of the results of the data studied in more detail.

Sudjana (2000) says that to the results of the mean interval seen from the number of classes used, namely:

Table 1. Mean

\begin{tabular}{|c|c|c|}
\hline Interval & $\begin{array}{c}\text { Product Innovation } \\
\text { Variables }\end{array}$ & $\begin{array}{c}\text { Purchase } \\
\text { Decision }\end{array}$ \\
\hline $1.00-1.79$ & Very Bad & Very Bad \\
\hline $1.80-2.59$ & Not Good & Not Good \\
\hline $2.60-3.39$ & Quite Good & Quite Good \\
\hline $3.40-4.19$ & Good & Good \\
\hline $4.20-5.00$ & Very Good & Very Good \\
\hline
\end{tabular}

Source : Sudjana(2000: 79)

Table 2. Correlation

\begin{tabular}{|c|c|}
\hline Interval & Relationship Strength \\
\hline $0,00-0,199$ & Very Low \\
\hline $0,20-0,399$ & Low \\
\hline $0,40-0,599$ & Average \\
\hline $0,60-0,799$ & Strong \\
\hline $0,80-1,000$ & Very Strong \\
\hline
\end{tabular}

Source : Widiyanto(2013: 182)

The coefficient of determination of the effect of product innovation on purchasing decisions can be used the formula, namely:

$\mathrm{KD}=\mathrm{r}^{2} \mathrm{x} 100 \%$

\section{Result and Discussion}

\section{Descriptive Innovative Characteristics}

To be able to see the descriptive magnitude of each variable explained in each sub-variable, researchers used descriptive statistics that were processed using SPSS 16.0 to then get an average value for each sub-variable described as follows:

Table 3. Mean of Product Innovation

Tourism Research Journal, Volume 4 (2), 2020 
Purchase Decision: Was It Affected By Product Innovation?

(Purchase In Sour Sally Gandaria City South Jakarta)

\begin{tabular}{|c|c|c|}
\hline SubVariable & Mean & Information \\
\hline Excellence & 3.70 & Good \\
\hline Compatibility & 3.62 & Good \\
\hline Complexity & 3.80 & Good \\
\hline Communicability & 3.32 & Quite Good \\
\hline Average & $\mathbf{3 . 6 1}$ & Good \\
\hline
\end{tabular}

Source: Primary Data (2019)

Based on table 3 above, it can be seen that the product innovation variable obtained an average mean of 3.61. If seen in the table, it can be stated that the product innovation at Sour Sally Gandaria City Jakarta is in a good category. It can also be seen about each sub variable in the product innovation variable where the relative superiority, compatibility, and complexity are in a good category while the ability to be communicated in the category is quite good.

Table 4. Mean of Purchase Decision

\begin{tabular}{|c|c|c|}
\hline SubVariable & Mean & Information \\
\hline Problem Recognition & 3.84 & Good \\
\hline Information search & 3.14 & Quite Good \\
\hline Alternative Evaluation & 3.56 & Good \\
\hline Purchase Decision & 3.38 & Quite Good \\
\hline Post Purchase Behavior & 3.72 & Good \\
\hline Average & $\mathbf{3 . 5 3}$ & Good \\
\hline
\end{tabular}

Source: Primary Data (2019)

Based on the table above, it can be seen that the purchase decision variable obtained an average mean of 3.53. If seen in table 3, it can be stated that the purchase decision at Sour Sally Gandaria City Jakarta is in a good category. It can also be known about each sub variable in the purchase decision variable where the introduction of problems, alternative evaluation, and post-purchase behavior in the good category while searching for information and purchasing decisions in the category is quite good.

\section{Correlation between Product Innovation and Purchasing Decisions}

Based on this study's purpose, one of them is to find out how much influence between product innovation on purchasing decisions at Sour Sally Gandaria City Jakarta. The researchers used SPSS 16.0 software to simplify the calculation process, and the results of the calculation are as follows: 
Purchase Decision: Was It Affected By Product Innovation?

(Purchase In Sour Sally Gandaria City South Jakarta)

Table 5. Correlation

\begin{tabular}{|r|r|r|r|}
\hline \multicolumn{2}{|c|}{} & Inovasi Produk & $\begin{array}{c}\text { Keputusan } \\
\text { Pembelian }\end{array}$ \\
\hline Spearman's rho & $\begin{array}{c}\text { Inovasi Produk } \\
\text { Correlation Coefficient } \\
\text { Sig (2-tailed)N }\end{array}$ & 1.000 & $.662^{*}$ \\
\cline { 2 - 4 } & &. & .000 \\
\cline { 2 - 4 } & Keputusan Pembelian & 89 & 89 \\
\cline { 2 - 4 } & Correlation Coefficient & $.662 *$ & 1.000 \\
\cline { 2 - 4 } & Sig (2-tailed)N & .000 & 89 \\
\hline
\end{tabular}

$* *$ Correlation is significant at the 0.01 level(2-tailed).

Source: Primary Data (2019)

To see the level of relationship that occurs, a correlation coefficient of 0.662 is used on a scale of $0.60-0.799$, which means that based on the table above, the correlation between product innovation and purchasing decisions in Sour Sally Gandaria City Jakarta is strong.

The correlation value is 0.662 greater than 0 . The relationship that occurs is positive. So, if product innovation increases, purchasing decisions will also increase, and vice versa.

The significance value of the correlation of product innovation and purchasing decisions of 0.000 is smaller than 0.05 , so that the two variables are significant. In other words, product innovation has a significant influence on purchasing decisions.

\section{Coefficient of Determination}

After being tested with the coefficient of determination:

$\mathrm{KD}=\mathrm{r}^{2} \mathrm{x} 100 \%$

$$
\begin{gathered}
=0,662^{2} \times 100 \% \\
=43.82 \%
\end{gathered}
$$

Then it can be said that the purchasing decision at Sour Sally Gandaria City Jakarta is influenced by product innovation by $43.82 \%$ and $56.18 \%$ is influenced by other variables not examined in this study.

\section{E. Conclusion and Suggestion Conclusion}

Product Innovation at Sour Sally Gandaria City Jakarta in the good category with an average of 3.61 with sub-variables are relative excellence, compatibility, and complexity in the good category while the ability to be communicated in the category is quite good.

Purchasing Decisions at Sour Sally Gandaria City Jakarta in the good category with an average mean of 3.53 with sub-variables, namely problem recognition, alternative evaluation, and post-purchase behavior in the good 
Purchase Decision: Was It Affected By Product Innovation?

(Purchase In Sour Sally Gandaria City South Jakarta)

category while information search and purchasing decisions in the category are quite good.

The level of relationship between product innovation and purchasing decisions is strong, significant, and positive because a correlation coefficient of 0.662 means that product innovation can influence purchasing decisions.

The contribution of the influence of product innovation on purchasing decisions is $43.82 \%$, and the remaining $56.18 \%$ is influenced by other variables not examined in this study.

\section{Suggestion}

Based on the sub-variable, the ability to communicate to the product innovation variable is quite good. It is recommended that Sour Sally regulates more ways or strategies so that consumers' benefits after making a purchase decision are more communicated among consumers. By evaluating this strategy, it is hoped that Sour Sally's product innovation will be better known to the public and will make the community interested until the purchasing decision is finally made.

Based on information search and purchase decision sub-variables on the purchase decision variable including the category quite well, it is recommended that Sour Sally shows more products or promotes products through mass media or social media accounts so that consumers are interested in finding information and is expected to occur buying decision.

\section{REFERENCES}

Anatan, Lina., \& Ellitan, Lena. (2009). Manajemen Sumber Daya Manusia Dalam Bisnis Modern. Bandung: Alfabeta.

Basu, Swastha., \& Sukotjo, Ibnu. (2007). Pengantar Bisnis Modern. Yogyakarta: Liberty.

Fitriana, R., Amrullah, A., \& Suryani, I. (2020). The Impact of Beauty Bloggers' Online Review towards Shopping Tour Interest of Cosmetic Products in Jakarta. TRJ (Tourism Research Journal), 4(1), 12-24.

Indriany. (2012). Studi Mengenai Orientasi Inovasi, Pengembangan Produk Dan Efektifitas Promosi Sebagai Sebuah Strategi Untuk Meningkatkan Kinerja Produk. Jurnal Studi Manajemen Organisasi, vol. 3, no. 2, pp. 82-92, Nov. 2012.

Kotler, Philip., \& Keller, Kevin Lane. (2012). Marketing Management. New Jersey: Prentice-Hall Published.

Kotler, Philip., \& Keller, Kevin Lane (2009). Manajemen Pemasaran. Jakarta: Erlangga.

Kotler, Philip. (2002). Manajemen Pemasaran. Jakarta: PT. Prenhalindo,

Tourism Research Journal, Volume 4 (2), 2020 
Purchase Decision: Was It Affected By Product Innovation?

(Purchase In Sour Sally Gandaria City South Jakarta)

Mustika, A., \& Ahmadi, M. (2018). Teenagers Perception of Halal Food as an Option for Culinary Tourism 3rd International Seminar on Tourism (ISOT 2018). Advances in Social Science, Education and Humanities Research, volume 259. Atlantis Press.

Sangadji, Etta Mamang., \& Sopiah. (2013). Perilaku Konsumen. Yogyakarta: Andi. Sekaran, Uma. (2004). Metodologi Penelitian Untuk Bisnis. Jakarta: Salemba Empat.

Sudjana, Nana. (2000). Teknik Analisis Regresi dan Korelasi bagi Para Peneliti. Bandung: Sinar Baru Algensindo.

Sugiyono. (2001). Metode Penelitian Administrasi. Bandung: Penerbit Alfabeta.

Swantari, A., Gantina, D., \& Festivalia, F. (2019). Analysis of The Effect of Price Determination on Hotel Revenue (Hotel Case in Puncak, Bogor). TRJ (Tourism Research Journal), 3(2), 188-202.

Tjiptono, Fandy, (2014). Pemasaran Jasa. Yogyakarta: Andi.

Widiyanto, Agus Mikha. (2013). Statistika Terapan. Konsep Dan Aplikasi Dalam Penelitian Bidang Pendidikan, Psikologi Dan Ilmu Sosial Lainnya. Jakarta: PT Elex Media Komputindo. 